\title{
Study Fenomenologi Pengalaman Perawat Dalam Memberikan Asuhan Keperawatan Pada Pasien Covid-19
}

\author{
Mila Triana Sari*, Miko Eka Putri, Daryanto \\ Departement of Nursing, Baiturrahim School of Health Science \\ *Correspondence email: milatrianasari73@gmail.com
}

\begin{abstract}
Abstrak. Corona Virus telah menyebabkan 3 wabah besar penyakit didunia selama 2 dekade terakhir yaitu SARS, MERS, dan Covid-19. Tingginya angka kejadian corona virus menyebabkan bertambahnya jumlah pasien dirumah sakit. Perawat adalah tenaga kesehatan yang paling sering kontak dengan pasien, serta memiliki tantangan untuk tetap memberikan asuhan keperawatan yang profesional dengan resiko tertular atau menjadi korban Covid-19. Penelitian ini bertujuan untuk mengidentifikasi pengalaman perawat selama merawat pasien dengan Covid-19. Penelitian ini merupakan penelitian Kualitatif dengan pendekatan Fenomenology yang dilakukan di Rumah Sakit Kota Jambi dari September 2020 Sampai Agustus tahun 2021. Populasi dalam penelitian ini Perawat yang berdinas dirumah sakit rujukan Covid-19. Teknik pengambilan sampel dengan Purposive Sampling dengan jumlah partisipan 13 orang, pengumpulan data dilakukan dengan wawancara Mendalam, via Telepone, dan observasi. Data yang dikumpulkan dianalisis dengan metode Creswell. Berdasarkan hasil penelitian didapatkan lima tema yaitu Pengetahuan tentang Covid-19, Loyalitas merawat pasien Covid-19, Perasaan merawat pasien Covid-19, Upaya mengurangi resiko penularan Covid-19, serta dukungan managemen RS dan keluarga terhadap perawat. Simpulan penelitian ini adalah sikap profesionalisme perawat tetap yang utama dalam merawat pasien Covid-19 meskipun perawat dibayangi oleh perasaan takut dan cemas saat merawat pasien Covid-19. Upaya yang perlu dilakukan adalah pelatihan pelatihan terkait askep covid-19 terbaru, dukungan keluarga dan lingkungan sosial serta pendampingan dan peningkatan spiritualitas perawat.
\end{abstract}

Kata kunci: Pasien Covid-19; Merawat; Perawat

Abstract. Corona virus has caused 3 major disease outbreaks in the world over the last 2 decades, namely SARS, MERS, and Covid-19. The high number of cases of the corona virus has led to an increase in the number of patients in hospitals. Nurses are health workers who have the most frequent contact with patients, and have challenges to continue to provide professional nursing care at the risk of contracting or becoming a victim of Covid-19. This study aims to identify the experiences of nurses while caring for patients with Covid-19. This study is a qualitative research with a phenomenological approach that was carried out at the Jambi City Hospital from September 2020 to August 2021. The population in this study was nurses who served at the Covid-19 referral hospital. The sampling technique was purposive sampling with 13 participants, data collection was done by in-depth interviews, via telephone, and observation. The data collected were analyzed by the Creswell method. Based on the results of the study, five themes were obtained, namely Knowledge about Covid-19, Loyalty in caring for Covid-19 patients, Attention to caring for Covid-19 patients, Efforts to reduce the risk of Covid-19 transmission, and support from hospital management and families for nurses. The conclusion of this study is that the professionalism of nurses remains the main thing in treating Covid-19 patients even though nurses are overshadowed by feelings of fear and anxiety when treating Covid-19 patients. Efforts that need to be made are training related to the latest Covid-19 health care services, family and social support, as well as mentoring and improving the spirituality of nurses.

Keywords: Covid-19 Patient; Caring; Nurse

\section{PENDAHULUAN}

Corona virus disease 2019 (Covid-19) merupakan masalah global yang terjadi saat ini. Jumlah penderita Covid-19 saat ini mengalami peningkatan yang cukup signifikan. Total penderita covid di dunia hingga pertengahan oktober 2020 adalah 37 juta orang. Kasus covid-19 di Indonesia 19.328.952 orang, sejak diumumkan kasus pertama pada 2 maret 2020, Sedangkan untuk provinsi Jambi berjumlah 790 kasus. (Kemenkes RI, 2020).

Penyakit Covid-19 menimbulkan ketakutan dan kecemasan secara global sejak terjadinya pandemi. Jumlah kasus yang semakin meningkat dengan mortalitas yang tinggi tentunya sangat mengkhawatirkan khususnya bagi tenaga perawat yang merupakan garda terdepan dalam menangani kasus pandemi Covid-19 yang berskala global ini. Perawat adalah salah satu tenaga kesehatan yang terlibat secara langsung dan kontak dengan pasien selama 24 jam. Perawat berada pada risiko yang tinggi tertular penyakit dan infeksi dari Covid-19, bahkan The International Council Of Nurses (ICN) menyatakan ada sebanyak 90.000 tenaga kesehatan telah terinfeksi covid-19 (ICN, 2020), sedangkan di Indonesia perjuli 2021 tercatat 453 perawat meninggal akibat corona (Lapor Covid-19, 2020). Hal ini dapat menimbulkan ketakutan dan keengganan pada perawat untuk kontak dan merawat pasien Covid-19.

Beberapa penelitian terkait, yaitu penelitian Lai et all (2020) dengan judul "Mental Health Status of Doctors and Nurses During Covid-19 Epidemic in China menyimpulkan bahwa tenaga kesehatan memiliki resiko lebih besar terjadinya masalah kesehatan mental, saat 
mengobati pasien Covid-19, yaitu sebesar 44,6\% memiliki gejala kecemasan yang disebabkan karena perasaan tertekan. Selanjutnya penelitian yang dilakukan oleh Sun, et all (2020) menggunakan disain kualitatif berjudul "A qualitative study on the psychological experience of caregivers of Covid-19" didapatkan 4 tema yaitu emosi negatif yang muncul saat awal, coping diri penyesuaian psikologis, tanggung jawab profesional dan refleksi diri,dan emosi positif terjadi bersamaan dengan emosi negatif.

Survey awal yang dilakukan kepada perawat Covid-19 dirumah sakit, didapatkan bahwa pandemi Covid-19 menyebabkan perawat mengalami perubahan pada pekerjaan dan kehidupannya, perawat merasa cemas, stres saat melakukan kontak dengan pasien Covid-19, karena pasien Covid-19 merupakan sumber penularan, stigma keluarga dan masyarakat serta dijauhi oleh lingkungan sosial, akan tetapi mereka tetap berupaya memberikan pelayanan yang terbaik yang bisa mereka berikan. Selain itu, pemakaian baju hazmat dan APD lengkap dalam waktu yang lama juga membuat para perawat dan pasien menjadi tidak nyaman.

Fenomena diatas menampakkan bahwa perawat yang merawat pasien Covid-19 memiliki kekhawatiran dan kecemasan takut tertular virus corona dan menularkan virus kepada keluarga dan orang-orang terdekat, dijauhi lingkungan sosial yang berdampak mempengaruhi kondisi fisik dan mental perawat. Penelitian ini bertujuan untuk menggali secara mendalam terkait pengalaman perawat dalam merawat pasien covid-19 serta menemukan arti dan makna dari pengalaman perawat tersebut.
Penelitian ini menggunakan rancangan (design) penelitian kualitatif deskriptif dengan pendekatan fenomenologi. Fenomenologi yaitu penelitian yang memberikan deskripsi, refleksi, interpretasi, dan modus riset yang menyampaikan intisari dari pengalaman kehidupan individu yang diteliti (Afiyanti, 2014) yang bertujuan untuk mendeskripsikan atau mengambarkan dan menginterpretasi pengalaman atau fenomena yang terjadi atau dialami oleh seseorang (Creswell, 2013) dengan fokus penelitian adalah perawat yang merawat pasien Covid-19. Tiga belas partisipan dipilih dengan metode purposive sampling dengan kriteria inklusi perawat yang bekerja diruang perawatan Covid-19, bersedia menjadi partisipan dan hasil rapid test negatif saat dilakukan wawancara. Penelitian dilaksanakan di wilayah kota Jambi. Pengumpulan data dalam penelitian ini dengan wawancara mendalam (indepth interview) dan catatan lapangan (field note). Semua partisipan sudah mendapatkan penjelasan terlebih dahulu tentang prosedur penelitian dan hak-hak partisipan dengan menandatangani informed consent. Analisa data dilakukan dengan metode creswell (Creswell, 2013; Afiyanti, 2014).

\section{HASIL DAN PEMBAHASAN}

Penyajian hasil penelitian ini ini terbagi menjadi dua bagian, yaitu gambaran karakteristik partisipan dalam bentuk tabel distribusi frekuensi, dan pemaparan pengalaman perawat yang merawat pasien Covid-19. Gambaran karakteristik perawat dalam penelitian ini meliputi jenis kelamin, umur, pendidikan, dan lama bekerja dapat dilihat pada tabel dibawah ini:

\section{METODE}

\section{Karakteristik Demografi}

Tabel 1. Karakteristik Perawat

\begin{tabular}{cccccc}
\hline No Responden & Jenis Kelamin & Umur & $\begin{array}{c}\text { Tingkat } \\
\text { Pendidikan }\end{array}$ & $\begin{array}{c}\text { Lama Bekerja di } \\
\text { Rumah Sakit }\end{array}$ & $\begin{array}{c}\text { Lama Bekerja di } \\
\text { R Covid }\end{array}$ \\
\hline R1 & Perempuan & 37 Tahun & S.Kep & 16 Tahun & 4 Bulan \\
R2 & Perempuan & 35 Tahun & Ners & 10 Tahun & 6 Bulan \\
R3 & Perempuan & 44 Tahun & D-3 & 23 Tahun & 6 Bulan \\
R4 & Perempuan & 39 Tahun & S.Kep & 11 Tahun & 1 Bulan \\
R5 & Perempuan & 30 Tahun & D-3 & 08 Tahun & 9 Bulan \\
R6 & Perempuan & 39 Tahun & Ners & 15 Tahun & 6 Bulan \\
R7 & Laki-Laki & 29 Tahun & D-3 & 01 Tahun & 7 Bulan \\
R8 & Perempuan & 40 Tahun & D-3 & 19 Tahun & 4 Bulan \\
R9 & Laki-Laki & 33 Tahun & Ners & 11 Tahun & 1 Tahun \\
R10 & Laki-Laki & 26 Tahun & S.Kep & 04 Tahun & 1 Tahun \\
R11 & Laki-Laki & 28 Tahun & D-3 & 05 Tahun & 5 Bulan \\
R12 & Perempuan & 26 Tahun & D-3 & 04 Tahun & 2 Bulan \\
R13 & Perempuan & 42 Tahun & S.Kep & 12 Tahun & 6 Bulan \\
\hline
\end{tabular}

Berdasarkan tabel diatas didapatkan Karakteristik demografik partisipan yang merawat pasien Covid-19 sebagian besar perempuan ( 9 orang), dengan tingkat pendidikan setengahnya (enam orang) adalah D-3 Keperawatan, tiga partisipan berpendidikan Sarjana
Keperawatan, dan 3 partisipan adalah Ners, serta rentang umur partisipan $24-44$ tahun dengan lama bekerja di RS mulai dari 1 tahun s.d 23 tahun dan lama bekerja partisipan di Ruang Covid-19 bervariasi mulai dari satu bulan sampai dengan satu tahun. 


\section{Pengalaman Perawat Merawat pasien Covid-19}

Pengalaman perawat dalam merawat pasien Covid-19 sangat bermacam ragam, pada penelitian ini terdiri atas lima tema utama meliputi: 1.) Pengetahuan tentang Covid-19 dan perawatan pasien Covid-19, 2.) Perasaan merawat pasien Covid-19, 3.) Loyalitas dalam merawat pasien Covid-19, 4.) Upaya Mengurangi resiko penularan, 5.) Dukungan Managemen Rumah Sakit, dan Keluarga, yang dipaparkan sebagai berikut:

\section{Pengetahuan tentang Covid-19 \\ Pengetahuan tentang sumber penularan Covid-19}

Pengetahuan perawat mengenai Covid-19 mulai dari penyebab serta sumber penularan sangat bervariasi, rata-rata mengatakan droplet, bersentuhan langsung, serta lingkungan yang terpapar Covid-19, sebagaimana yang diungkapkan partisipan antara lain:

“...Melalui udara dari droplet, tindakan aerosol, bersalaman/kontak dengan orang yang terinfeksi..." ( R7)

"... Melalui percikan air liur seperti bersin, batuk, bersentuhan langsung dengan penderita Covid-19..." (R2)

“....Droplet...” $(R 4)$

“...Covid 19 berasal dari china yang ditularkan oleh hewan sejenis kelelawar ke manusia, sumber penularan dari pasien + covid19 ke manusia lain nya melalui kontak erat, lingkungan yang terpapar covid 19 dan droplet...." (R10)

\section{Pengetahuan tentang cara perawatan pasien dengan Covid-19}

Pengetahuan adalah segala sesuatu yang diketahui perawat tentang cara memberikan asuhan keperawatan pada pasien Covid-19, sebagaimana ungkapan partisipan sebagai berikut:

“...Pada pasien yang non komplikasi atau non comorbid yg tanpa gejala, cukup dgn konsumsi buah buahan, sayuran, konsumsi vit $c$, berjemur dan hindari stress, serta banyak minum air putih agar imun terjaga, pada pasien covid 19 non komplikasi tapi ada gejala, seperti demam, batuk, anosmia biasanya di tambahkan anti biotik aseltamivir dan acitromicin , pct, ambroxol dan tetap melakukan di poin pertama tadi. Jika sesak berat pasien di sarankan utk di rawat terapi yg diberikan tergantung dokter spesialis biasanya bersifat injeksi.dan pemberian oksigen yg cukup, Pada pasien covid 19 yg memiliki comorbid seperti DM, hipertensi, itu biasanya di cek dulu semua penyakit comorbid yang di derita pasien. Perawatannya tetap seperti point pertama tadi dan kolaborasi dengan dokter untuk terapi yang di butuh kan pasien sesuai dengan kriteria kebutuhan obat obatan pasien tersebut..." (R10)

“... Simptomatik, peningkatan asupan cairan dan daya tahan tubuh..." ( R6)

“... Jaga imun dengan cara makan yang bergizi minum vitamin, olahraga, istirahat yang cukup..." ( R2)

“...Pasien akan diberikan perawatan sesuai dengan keluhannya yang dikerjakan sesuai dengan SPO yang berlaku di ruang rawat isolasi covid-19..." ( R8)

".....Bagi orang tanpa gejala memberikan motivasi dan selalu untuk mengikuti anjuran dokter DPJP dan perawat menjaga dan perawat menjaga pasien covid19 bagi yang bergejala tetap kolaborasi dengan dokter DPJP pasien covid-19 masalah teraphy..." (RI1)

“...Tetap menerapkan protokol kesehatan, meminum vitamin..." (R13)

\section{Perasaan merawat pasien Covid-19}

Perasaan yang dimaksud disini terbagi perasaan perawat saat awal merawat pasien dan perasaan tentang pengalaman luar biasa yang dimiliki perawat selama memberikan asuhan keperawatan pada pasien Covid-19. Pada umumnya perawat yang merawat pasien diliputi rasa gugup, deg-deg an, merasa tidak siap, sedih dan menangis karena memakai Hazmat selama berjam-jam, cemas dan takut jika tertular maupun menularkan kepada keluarga dan orang lain, dan akhirnya berserah diri kepada Tuhan, sebagai berikut:

\section{Perasaan saat awal merawat pasien}

Seluruh partisipan mengungkapkan rasa takut, cemas dan tidak siap saat awal kontak dengan pasien, seperti yang disampaikan partisipan sebagai berikut...

“...Pertama yang saya rasakan itu takut, cemas..." (R10)

“... Perasaan awal deg-degan...” (R2)

“....Perasaan awal Sedih dan menangis, karena memakai hazmat begitu panas di tambah lagi masker yang di pakai berlapis..." (R13)

"...Perasaan di awal merasa stres dan cemas karena takut terkena virus Corona...” (R6)

“...Rasa takut pasti ada, tapi saya percaya Allah selalu ada bersama kita dan menjalaninya dengan ikhlas..." (R5)

"...Takut dan sedih...." saya merasa yakin Allah yang menghendaki semua. Saya BISA!...” (R8)

\section{Pengalaman setelah merawat pasien (minimal 1 bulan)}

Sebagian besar partisipan sudah mulai terbiasa, cemas berkurang dan ikhlas. Serta merasa bangga dan bahagia bila pasien covid-19 sembuh dan bisa pulang ke tengah keluarganya, antara lain.... 
“....lama lama Perasaan saya sudah biasa saja, takut berkurang, cemas berkurang, berserah diri kepada tuhan dan semangat demi raga yang lain.." (R10)

“... beberapa waktu di bawa santai aja..” (R2)

“....lama lama terbiasa, sudah jauh berkurang cemasnya (R13)

“....Setelah beberapa bulan merawat pasien Corona, Tingkat kecemasan saya berkurang...” (R6)

"....Alhamdulillah saya sudah bisa adaptasi dan tidak cemas, bangga dan bahagia apabila pasien cepat sehat..." (RI)

\section{Pengalaman Luar biasa}

“...Pengalaman luar biasa yang pernah saya alami dalam merawat covid 19 pasien covid $19+c k d+d m$ type II pasien dengan sesak hebat datang pada pukul 03.15, di saat saya memasuki ruangan dekontaminasi atau ruangan covid 19 dalam keadaan cemas dan takut, saya melihat pasien sudah perburukan sehingga penurunan kesadaran dengan cepat dari composmentis 15 menit kemudian langsung koma, sehingga pasien tidak ada nadi dan nafas dan di nyatakan meninggal dan prosedur penanganan pasien covid 19 yang henti nafas dan jantung tidak di lakukan RJP, pengalamannya cepat sekali terjadi perburukan dalam hitungan menit...” (R10)

"...pengalaman luar biasa memakai hazmat berjam jam sehingga sulit bernapas.. ”( R2)

“...pengalaman luar biasa saat merawat pasien dengan penurunan kesadaran, dimana saat itu ICU covid di RS lain pada penuh. Jadi kita harus lebih intensif lagi dalam perawatan dan kolaborasi dengan dokter....” ((R13)

“....Pengalaman luar biasa saat hampir 4 jam saya memakai apd lengkap dan harus mendorong pasien ke icu covid dan saat di pintu icu nafas saya sudah sangat sesak dan panas saat keluar pandangan sudah hitam, karena hipoksia dan saya harus memakai oksigen hampir 1 jam..." (Rl)

\section{Loyalitas dalam merawat pasien Covid-19}

Sebagian besar perawat memiliki rasa tanggung jawab yang besar dalam merawat pasien Covid-19, dan teridentifikasi dua motivasi yaitu motivasi intrinsik dan motivasi ekstrinsik sebagaimana berikut:

\section{Motivasi Intrinsik}

“... Kalau tidak kita siapa lagi,walau ada rasa cemas dan takut, Saat ini saya merasa tertantang dg adanya pandemik ini, APD yang lengkap ada diruangan Covid-19 jadi merasa lebih aman dg berbekal pada sharing2 teman pada tempat lain, Saya berusaha menjadi yang terbaik sebagai Hamba Allah SWT untuk menolong sesama...” (R8)

“... Dengan merawat pasien ini semoga cepat teratasi dan tidak ada lagi pasien covid yang lain yang memiliki cormobid..." ( RI)

"... Sabar, ikhlas dan tawakkal kepada Allah SWT, Lakukan yang terbaik, anggap saja pasien itu keluarga kita, tetap semangat..."( R10)

“... Menunjukkan bahwa pasien covid-19 itu tidak menakutkan seperti yang diberitakan diluar sana..." (R3)

“... Sudah menjadi tugas \& kewajiban saya sebagai perawat, selalu berdoa \& yakin akan perlindungan dari Allah..." ( R6)

\section{Motivasi Ekstrinsik}

“...ingin melihat pasien bisa sembuh melawan covid$19 . . . "(R 5)$

"...Selalu ingin melihat pasien berkumpul dengan keluarganya...” (R7)

\section{Upaya mengurangi resiko penularan}

Upaya mengurangi resiko penularan adalah segala sesuatu yang dilakukan perawat untuk mengurangi dan mencegah resiko penularan perawat tetap menganggap pasien adalah sumber infeksi sehingga tetap menerapkan kewaspadaan serta meminimalisir kontak langsung dengan pasien, namun ada juga perawat yang merasa terlindungi dan aman dengan pakaian APD Lengkap yang mereka gunakan selama memberikan asuhan keperawatan,

“... Bersama Tim buat waktu rencana tindakan serta perkiraan waktu, Memutuskan jumlah anggota Tim yang akan bersama dalam memberikan Askep, Kontak dg pasien dengan HP via VC sebelum masuk ke ruangan pasien, Gunakan APD level 3, Meminimalkan waktu untuk kontak dengan pasien,namun kebutuhan pasien tetap di utamakan serta mengajak pasien bekerjasama dengan proses perawatannya..." ( $R 8)$

“... Bekerja sesuai SOP memakai dan membuka baju hazmat, membatasi kunjungan secara langsung ke kamar pasien...” ( R4)

“...Menggunakan APD sesuai kebutuhan, membuka APD sesuai prosedur, berdoa....” ( R12)

“...Pegang teguh PPI nya dan 3M...” (R9)

“...Dengan menggunakan asmat, APD lengkap , setelah merawat pasien kami melepas baju APD secara hati hati bertahap setelah itu langsung mandi... Ketika pulang dinas kami mandi lagi.." ( R4)

Dukungan keluarga, dan Managemen Rumah Sakit 
“... Keluarga sebagian tidak mendukung bahkan di nikahan adek,saya tidak tidak perbolehkan datang. Sebagian lagi mendukung terutama suami, Bekerjasama dengan Dokter, mereka selalu bersama serta saling mengingatkan kita tetap harus menjalankan semua protokol kesehatan di mana pun, Manajemen selalu memberi semangat tuk jaga kesehatan dan jangan lupa bahagia,kata mereka. Awalnya hampir setiap hari mereka berkunjung termasuk Tim PPI..." ( R10)

“...keluarga mendukung dengan selalu mendoakan keselamatan saya dalam bekerja dan selalu mengingatkan saya untuk bekerja dengan aman, tim kesehatan dan manajemen rumah sakit mendukung dengan menyediakan tempat karantina, memberikan suplemen-suplemen kesehatan...” ( R5)

“...Dukungan keluarga dengan menerima pulang ke rumah walau pada awalnya takut, tim kesehatan lain tetap melakukan kerja sama dalam perawatan pasien, manajemen memfasilitasi bagi yang tidak diterima di rumah ataupun lingkungannya, memberikan tambahan nutrisi bagi tim petugas covid 19..." ( R1)

"...Dukungan dari keluarga berupa selalu mengingatkan kepada allah, berhati-hati dalam penggunaan APD, istirahat dan makanan yang bergizi, dukungan dari tim kesehatan lakukan sesuai SOP, tetap semangat, managemen rumah sakit berupa makanan dan minuman yang bergizi, serta vitamin..." ( R10)

“... Dukungan dari manajemen memenuhi kebutuhan APD bagi perawat, support dan doa dari keluarga dan nakes.. "(R6)

“.... Dukungan dari Rumah Sakit dalam memenuhi kebutuhan vitamin, extra puding dan alat kesehatan terhadap tenaga kesehatan yang terjun langsung di ruangan Covid.

\section{Pembahasan \\ Pengetahuan partisipan tentang Covid-19 dan perawatannya}

Pengetahuan partisipan tentang Covid-19 dan perawatan pasien Covid-19 yang tinggi ditemukan pada mayoritas partisipan. Hal ini terkait dengan tingkat pendidikan formal responden yang cukup tinggi (Diploma 3, Sarjana dan Ners). Hasil yang ditemukan ini sesuai dengan penelitian yang telah dilakukan oleh Sriyona (2008) dan Tzeng (2006) bahwa tingkat pengetahuan dan pendidikan seseorang dapat mempengaruhi kemampuan seseorang dalam berperilaku.

\section{Pengalaman merawat pasien}

Cemas yang dialami seseorang selama menjalankan pekerjaan merupakan tanda ditemukannya situasi yang sulit di lingkungan kerja. Penelitian ini menemukan adanya kecemasan yang dialami oleh sebagian besar responden. Adanya perasaan cemas dan stres ini menunjukkan bahwa perawat yang bertugas merawat pasien Covid-19 memang berhadapan dengan situasi sulit.

Namun, Perawat tetap peduli dengan pasien dan tetap memberikan yang terbaik bagi pasien yang sedang dirawat, membuktikan bahwa aspek caring perawat Indonesia adalah tinggi. Temuan ini sesuai dengan hasil penelitian yang dilakukan oleh Cronquest (2004) yang mencatat tingginya sikap caring perawat yang dinas di ruang ICU. Empati adalah suatu perilaku untuk sadar dan bereaksi secara mental dan emosional pada orang lain, perasaan simpati dan perhatian terhadap orang lain, khususnya pada orang lain yang menderita dengan menempatkan dirinya pada posisi orang lain tersebut sehingga orang lain seakan-akan menjadi bagian dalam dirinya (Prot S, (2014). Perasaan empati yang mendalam timbul karena pasien yang dirawat sendirian tanpa adanya keluarga yang menunggui, serta adanya pasien yang meninggal. Beberapa partisipan mengalami pengalaman yang luar biasa selama merawat pasien, misalnya senang bila pasien yang telah dinyatakan positif Covid-19 dapat sembuh kembali.

Perawat ketika menanggapi adanya persoalan yang terjadi pada klien. Memahami klien berarti perawat telah menghindari asumsi, berfokus pada klien dan ikut serta dalam hubungan Caring dengan klien yang telah memberikan informasi dan memberikan penilaian klinis. Memahami klien merupakan inti suatu proses yang digunakan perawat dalam membuat suatu keputusan klinis. Perawat yang telah membuat keputusan klinis yang akurat dan tepat dengan konteks pemahaman yang baik, akan dapat meningkatkan hasil berupa kesehatan klien, klien akan mendapatkan pelayanan pribadi, nyaman, dukungan dan pemulihan atau kesembuhan (Potter \& Perry, 2009).

Kesadaran akan manfaat pemakaian Alat Pelindung Diri (APD) perlu ditanamkan pada setiap tenaga kerja, karena perasaan tidak nyaman (risih, panas, berat, terganggu) merupakan salah satu alasan mengapa seorang pekerja tidak menggunakan Alat Pelindung Diri (APD). Pembinaan secara terus menerus akan dapat meningkatkan kesadaran dan wawasan mereka. Salah satu cara yang sangat efektif adalah dengan melakukan pelatihan-pelatihan. Peningkatan pengetahuan dan wawasan akan menyadarkan tentang betapa pentingnya penggunaan Alat Pelindung Diri (APD), sehingga akan sangat efektif dan benar dalam penggunaannya.

\section{Loyalitas Merawat Pasien}

Sebagian besar partisipan menyatakan kesediaannya merawat pasien Covid-19. Keinginan untuk meninggalkan pekerjaan tidak tercetus dari partisipan meskipun mereka memiliki resiko tertular penyakit. Hal ini didasari oleh motivasi intrinsik dari diri 
partisipan akan tanggung jawab dan panggilan jiwa merawat pasienCovid-19.

Motivasi intrinsik adalah motivasi yang muncul atau berasal dari dalam diri sendiri. Motivasi ini terkadang dapat muncul tanpa adanya pengaruh dari luar. Biasanya seseorang atau individu yang merasa termotivasi secara intrinsik lebih mudah terdorong untuk mengambil tindakan. Bahkan, mereka dapat memotivasi dirinya sendiri tanpa perlu untuk dimotivasi oleh orang lain. Adapun faktor-faktor yang mempengaruhi motivasi intrinsik adalah : a. Kebutuhan. Seseorang melakukan suatu kegiatan atau aktivitas didasari dari adanya faktorfaktor kebutuhan. b. Harapan. Seseorang termotivasi oleh adanya suatu harapan yang bersifat akan pemuasan diri. Keberhasilan dan harga diri meningkat dan menggerakkan seseorang menuju pencapaian suatu tujuan. c. Minat. Minat merupakan suatu rasa lebih suka dan rasa keinginan pada sesuatu hal tanpa ada yang menyuruhnya (Suhardi, 2013).

Hasil yang ditemukan ini sesuai dengan penelitian yang telah dilakukan oleh Permana I. S., Sedjati R. S \& Kusniasih N (2017) menyatakan bahwa motivasi Intrinsik akan berpengaruh positif secara signifikan terhadap kinerja perawat di RSUD 45 Kuningan. Motivasi Intrinsik yang dilakukan dengan baik maka kinerja perawat pun akan menjadi meningkat. Begitu juga sebaliknya jika motivasi intrinsik yang dilakukan buruk, akan dapat menurunkan tingkat dari kinerja perawat. Motivasi intrinsik mencakup adanya : tanggung jawab, pengakuan dan pengembangan perawat. Hal ini didapatkan dari perhatian pihak managemen dan pemerintah mulai dari pusat sampai daerah terhadap keselamatan dan keamanan perawat. Selain itu perawat memberikan asuhan keperawatan pada pasien Covid-19 dikarenakan motivasi ekstrinsik.

Motivasi ekstrinsik adalah motivasi yang muncul atau berasal karena adanya suatu pengaruh dari luar diri seorang tersebut. Motivasi ekstrinsik menjadi pemicu untuk membuat seseorang termotivasi. Pemicu motivasi ekstrinsik dapat berupa adanya uang, bonus, insentif, promosi jabatan, penghargaan, pujian dan sebagainya. Motivasi ekstrinsik memiliki suatu kekuatan untuk mengubah kemauan atau keinginan seseorang dari yang tidak mau hingga mau melakukan sesuatu hal. Adapun factor-faktor yang mempengaruhi motivasi ekstrinsik adalah : a. Dorongan keluarga. Dorongan keluarga merupakan salah satu dari faktor pendorong (reinforcing factor) yang mampu mempengaruhi perilaku seseorang. b. Lingkungan. Lingkungan merupakan tempat dimana seseorang tinggal atau tempat seseorang dalam bekerja. Lingkungan memiliki peranan yang besar untuk memotivasi seseorang. c. Imbalan. Seseorang akan dapat termotivasi dengan disediakannya adanya imbalan setelah melakukan suatu aktivitas atau kegiatan tertentu (Suhardi, 2013).

Hasil yang ditemukan ini sesuai dengan penelitian yang telah dilakukan oleh Permana I. S., Sedjati R. S \& Kusniasih N (2017) menyatakan bahwa motivasi ekstrinsik berpengaruh positif secara signifikan terhadap kinerja perawat di RSUD 45 Kuningan. Motivasi ekstrinsik yang mendukung partisipan tetap untuk melaksanakan kewajiban mereka sebagai perawat adalah dukungan dari instansi tempat mereka bekerja seperti : adanya reward berupa tambahan uang insentif, adanya makanan tambahan, adanya sertifikat dari PPNI bagi perawat yang merawat pasien di ruang isolasi Covid-19, adanya dukungan dari orang lain dan peralatan pelindung diri yang memadai, suport nutrisi dan vitamin yang cukup serta jadwal dinas dan libur perawat yang diatur sedemikian rupa dari pihak managemen dapat meningkatkan motivasi ekstrinsik perawat yang merawat pasien covid-19.

\section{Upaya mengurangi resiko tertular penyakit}

Penggunaan secara rasional dan konsisten Alat Pelindung Diri (APD) yang tersedia serta higiene dari sanitasi tangan yang memadai juga akan membantu mengurangi penyebaran infeksi (Kemenkes RI, 2013). Penggunaan Alat Pelindung Diri (APD) sangat penting untuk digunakan ketika sedang bekerja di rumah sakit. penggunaan APD harus sesuai Standar Operasional Prosedur (SOP). Alat Pelindung Diri (APD). digunakan untuk melindungi dari penularan virus khususnya Covid19. Untuk tenaga kesehatan yang melakukan suatu tindakan pelayanan kesehatan berisiko tinggi seperti tindakan bedah atau tindakan lain yang memiliki risiko penularan tinggi harus menggunakan Alat Pelindung Diri (APD) yang telah memenuhi standar baik dari mutu dan keamanan (Kemenkes RI, 2020).

Mayoritas Partisipan tetap menganggap pasien adalah sumber infeksi sehingga mereka tetap menerapkan kewaspadaan selama kontak dengan pasien. Ada yang meminimalkan kontak langsung dengan pasien. Upaya lain yang dilakukan adalah meminimalkan kontak perawat dengan pasien. Upaya ini sekalipun maksudnya baik, tetapi jika dikaitkan dengan profesi perawat ditemukan keadaan yang kontradiktif karena secara moral perawat wajib menjaga pasien seoptimal mungkin. Merancang kegiatan serta waktu yang diperlukan dalam merawat pasien Covid-19 yang dilakukan dengan jaga bergantian diharapkan dapat mengatasi hal ini. Metode ini dinilai cukup efektif karena perawatan optimal tetap dapat diberikan.

Kewaspadaan baku merupakan tonggak yang harus selalu untuk diterapkan di semua fasilitas pelayanan kesehatan dalam memberikan pelayanan kesehatan yang aman bagi semua pasien dan mengurangi terjadinya risiko infeksi lebih lanjut. Kewaspadaan Standar meliputi : kebersihan tangan dan penggunaan Alat Pelindung Diri (APD) untuk menghindari kontak langsung dengan darah, cairan tubuh, sekret (termasuk sekret pernapasan) dan kulit pasien yang terluka 
(Kemenkes RI, 2013).

Hasil yang ditemukan ini sesuai dengan penelitian yang telah dilakukan oleh Putri S. I \& Anulus A (2020) serta penelitian May DYS et al., (2021) menunjukkan bahwa petugas layanan kesehatan berusaha untuk mencegah terjadinya penularan Covid-19 dengan melakukan jarak sosial, menggunakan Alat Pelindung Diri (APD) yang tepat, mencuci tangan, skrining dalam melakukan kunjungan dan telemedicine. Petugas kesehatan memiliki tanggung jawab tambahan untuk memberikan perlindungan kepada pasien dan diri mereka sendiri.

\section{Dukungan Managemen Rumah Sakit dan Keluarga}

Dukungan sosial keluarga adalah sebuah proses yang terjadi sepanjang masa kehidupan, sifat dan jenis dukungan sosial keluarga berbeda-beda dalamberbagai tahap siklus kehidupan. Namun demikian, dalam semua tahap siklus kehidupan, dukungan sosial keluarga membuat keluarga mampu berfungsi dengan berbagai kepandaian dan akal. Sebagai akibatnya, hal ini meningkatkan kesehatan dan adaptasi keluarga. Dukungan sebagai pemberian dorongan atau pengobatan semangat dan nasihat kepada orang lain dalam satu situasi pembuatan keputusan, sebagai sesuatu yang didukung, sokongan, bantuan. Keluarga adalah satu kelompok individu yang terkait oleh ikatan perkawinan atau darah secara khusus, mencakup seorang ayah, ibu, dan anak. Dukungan dapat berarti bantuan yang diterima seseorang dari orang lain, dukungan ini biasanya diperoleh dari lingkungan sosial sekitarnya yakni seperti orang-orang yang terdekat, termasuk didalamnya adalah anggota keluarga, orang tua, dan teman (Istiyani, 2018). Berdasarkan beberapa pengertian dukungan keluarga diatas, maka dukungan keluarga pada perawat merupakan dukungan yang diterima perawat dari keluarga, dukungan yang diterima perawat meliputi sikap, tindakan dan penerimaan keluarga terhadap pekerjaan dan tanggung jawab perawat.

Dukungan keluarga yang dilakukan antara lain menerima bahwa setelah pulang jaga, perawat tidak langsung pulang kerumah, namun transit dulu di tempat tertentu untuk mengurangi resiko penularan dan tidak membedakan dan berstigma negatif terhadap perawat yang jaga diruang Covid-19.

\section{SIMPULAN}

Hasil penelitian ini memberikan pemahaman secara mendalam dan menyeluruh tentang pengalaman perawat dalam memberikan asuhan keperawatan pada pasien Covid-19, yang teridentifikasi pada lima tema utama yaitu pengetahuan tentang Covid-19 dan cara perawatannya, perasaan saat merawat pasien Covid-19, Loyalitas dalam merawat pasien Covid-19, Upaya mengurangi resiko penularan Covid-19 serta dukungan managemen RS dan dukungan keluarga pada perawat yang merawat pasien Covid-19. Hasil lain yang ditemukan adalah loyalitas perawat yang tinggi dalam memberikan asuhan keperawatan pada pasien Covid-19 meskipun dibayangi dengan rasa cemas akan resiko penularan serta kepatuhan perawat untuk menggunakan Alat Pelindung Diri sesuai ketentuan Kemenkes RI tahun 2020. Selain itu dukungan managemen RS dan keluarga merupakan suport utama perawat pada saat melaksanakan dan setelah selesai dinas demi keamanan dan kenyamanan perawat yang dinas diruang Covid-19.

\section{Saran}

Pihak managemen rumah sakit untuk memberikan pelatihan-pelatihan dan up date ilmu terbaru terkait Covid-19 sehingga dapat meningkatkan pengetahuan perawat dalam memberikan asuhan keperawatan pada pasien Covid-19, selain itu perlunya bimbingan rohani dan spiritual, serta psikologi dalam menguatkan mental perawat yang berdinas di ruang Covid-19.

\section{DAFTAR PUSTAKA}

Afiyanti, Y. (2014). Metodologi Penelitian Kualitatif dalam Riset Keperawatan. Jakarta: Rajawali Pers

Cronquest, A. (2004). Cariong for moral obligation and work responsibility in intensive care nursing. Sage Publication

Creswell, J. (2013). Research DesignPendekatan Metode Kualitatif, Kuantitatif dan Campuran .Yogyakarta: Pustaka Pelajar.

ICN. (2020). ICN Calls For Data On Healthcare Worker infection Rates and Deaths, 6 May 2020. https;//www.icn.ch/news/icn-calls-datahealthcare-worker-infection-rates-and-deaths

Istiyani, (2018) Hubungan Dukungan Keluarga Dengan Self Care Behavior Penderita Dibetes Millitus Tipe 2. Undergraduate thesis, STIKes Insan Cendekia Medika Jombang. Repository Tersedia dari : http://repo.stikesicme-jbg.ac.id/1881/

Kemenkes Kesehatan Republik Indonesia. Pedoman Kesiapsiagaan Menghadapi COVID-19 versi 3 Maret 2020. Jakarta: Kementerian Kesehatan Republik Indonesia. 2020; 25.

Kemenkes RI. (2013). Pedoman Pencegahan Dan Pengendalian Infeksi Kasus Konfirmasi Atau Probabel Infeksi Virus

Lai, J., Ma, S., Wang, Y., Cai, Z., Hu, J., Wei, N., Li, R. (2020). Factors Associated With Mental Health Outcomes Among Health Care Workers Exposed to Coronavirus Disease 2019. JAMA, 3(3), 1-12. https://doi.org/10.1001/jamanetworkopen.2020.39 $\underline{76}$ 
Lapor Peduli Covid-19. (2020). Jumlah Kematian Tenaga Kesehatan akibat Covid-19 (per 21 Juli 2021). Tersedia dari : https://databoks.katadata.co.id/datapublish/2021/0 7/21/sebanyak-1459-tenaga-kesehatan-meninggalakibat-covid-19

May DYS,et al (2021) Studi Fenomenologi Pengalaman Perawat dalam Merawat Pasien Suspect Covid-19, Jurnal Ilmu Keperawatan Medical Bedah; (4) 1 Mei 2021

Permana I. S., Sedjati R. S \& Kusniasih N. (2017). Pengaruh Faktor Motivasi Intrinsik Dan Ekstrinsik Terhadap Kinerja Perawat di Rsud 45 Kabupaten Kuningan. JURNAL EKONOMI ISSN: 23027169 Vol. 6 No. 1 Januari - Juni 2017.

Potter P. A \& Perry A. G. (2009). Fundamental of nursing, 7th edition. Singapore : Elsevier.

Prot S. (2014). Long-Term Relations Among ProsocialMedia Use, Emphaty, and Prosocial Behavior. Journal Association for Psychological Science Vol 25 (2) 358-368.

Putri S. I \& Anulus A. (2020). Preventive actions to minimizing the coronavirus disease 19 (COVID19) transmissions among health workers: a systematic review. Journal of the Medical Sciences ( Berkala Ilmu Kedokteran ) Volume 52, Number 3(SI), 2020; 110-119. http;//dx.doi.org/10.19106/JmedSciSI0052032020 12

Suhardi. (2013). The Science of Motivation (Kitab Motivasi). Jakarta : PT Gramedia

Sun N, Wei L, Shi S, Jiao D, Song R, Ma L, et al. A qualitative study on the psycological experience of caregivers of COVID-19 patients, Am J Infect Control. 2020;48(6):592-8.

Sriyona, AYN. (2008) Analisis Fenomenologi Tentang Pengalaman Perawat Memberikan Asuhan Keperawatan Kepada Pasien dengan Avian Influenza, Jurnal Keperawatan Indonesia. ; (12) 16

Tzeng, H-M., C-Y. (2006). Nurses/fears and professional obligations concerning possible human to human avian flu. Nursing Ethics, 11, 277-89. 